Article

\title{
Assessment of General Public's Knowledge and Opinions towards Antibiotic Use and Bacterial Resistance: A Cross-Sectional Study in an Urban Setting, Rufisque, Senegal
}

\author{
Oumar Bassoum ${ }^{1,2, *}$, Ndèye Marème Sougou ${ }^{1,2}$, Mayassine Diongue ${ }^{1,2}$, \\ Mamadou Makhtar Mbacke Lèye ${ }^{1,2}$, Mouhamad Mbodji ${ }^{3}$, Djibril Fall ${ }^{3}$, Ibrahima Seck ${ }^{1,2}$, \\ Adama Faye ${ }^{1,2}$ and Anta Tal-Dia ${ }^{1,2}$ \\ 1 Department of Public Health and Preventive Medicine, Faculty of Medicine, Pharmacy and Odontology, \\ University Cheikh Anta Diop, 5005 Dakar-Fann, Senegal; ndeyemareme.sougou@ucad.edu.sn (N.M.S.); \\ mayassine.diongue@ucad.edu.sn (M.D.); mamadou.leye@ucad.edu.sn (M.M.M.L.); \\ ibrahima.seck@ucad.edu.sn (I.S.); adama.faye@ucad.edu.sn (A.F.); anta.dia@ucad.edu.sn (A.T.-D.) \\ 2 Institute of Health and Development, University Cheikh Anta Diop, 16390 Dakar-Fann, Senegal \\ 3 Laboratory of Therapeutic and Organic Chemistry, Faculty of Medicine, Pharmacy and Odontology, \\ University Cheikh Anta Diop, 5005 Dakar-Fann, Senegal; mbodjimouha28@gmail.com (M.M.); \\ djibril.fall@ucad.edu.sn (D.F.) \\ * Correspondence: bassoum.oumar@gmail.com or oumar.bassoum@ucad.edu.sn; Tel.: +221-33-824-98-78; \\ Fax: +221-33-825-36-48
}

Received: 29 May 2018; Accepted: 8 August 2018; Published: 20 September 2018

\begin{abstract}
Background: Bacterial resistance is a major public health problem worldwide. One solution to this scourge is to sensitize the general public on rational use of antibiotics. Our goal was to assess people's knowledge and opinions about antibiotic use and bacterial resistance in an urban setting. Method: We performed a cross-sectional study. A convenience sampling was done. A questionnaire was administered to 400 persons during face-to-face interviews. Results: Most respondents thought that antibiotics are effective against colds / flu $(69.8 \%)$, cough $(72.3 \%)$ and sore throat $(64.4 \%)$. At the same time, $42.8 \%$ stated that antibiotic therapy can be stopped as soon as the symptoms disappear. Only $8.8 \%$ and $41.8 \%$ of people knew that handwashing and vaccination prevented bacterial resistance. Globally, $7 \%$ of people had a good knowledge. Socio-demographic variables were not associated with the level of knowledge. The main sources of information were entourage and pharmacy staff. Regarding the opinions, $78.3 \%$ of surveyed participants the people thought that that people overuse antibiotics. Additionally, $28 \%$ said that they have no role to play against bacterial resistance. Conclusion: People living in an urban setting had a low knowledge about antibiotic use and bacterial resistance. There is a need to implement awareness campaigns. Further studies on population practices toward antibiotic use are necessary.
\end{abstract}

Keywords: knowledge; opinions; general public; antibiotic use; bacterial resistance; Rufisque; Senegal

\section{Introduction}

Antibiotics are a category of antimicrobial drugs that revolutionized modern medicine [1]. They have improved health and saved millions of lives [2,3]. Thus, they were considered as "miracle drugs" into thinking that infectious diseases would become a problem of the past [3]. However, this hope has not been realized to the extent that their effectiveness is compromised by the emergence of bacterial resistance [4]. The World Health Organization (WHO), in his first global report on surveillance of antimicrobial resistance, estimates that it is occurring across many infectious agents and has spread 
to all regions of the world [5]. This report reveals high levels of resistance to last resort treatment for life-threatening infections caused by Klebsiella pneumoniae. In addition, Escherichia coli has become resistant to fluoroquinolones, which are among the most widely used antibiotics for the treatment of urinary tract infections. In 2014, the total number of multidrug-resistant tuberculosis cases is estimated at 480,000, of which $10 \%$ were extensively drug-resistant [6]. In developing countries, Antimicrobial resistance is a significant issue for health care. In Australia, vancomycin-resistant enterococci and community-acquired methicillin-resistant Staphylococcus aureus have emerged as major antibiotic resistant bacteria [7]. In United States (US), the Centers for Disease Control and Prevention (CDC) have published a list of antibiotic resistant bacteria. The threat level of each bacteria is categorized as urgent (e.g., carbapenem-resistant Enterobacteriaceae), serious (e.g., drug-resistant Salmonella Typhi) and concerning (e.g., Erythromycin-resistant Group A streptococcus) [8].

In sub-Saharan Africa, the extent of the problem is not sufficiently known due to the unavailability of data [5], but recent studies have shown resistance to the most commonly used antibiotics such as amoxicillin, ampicillin, gentamicin and ceftriaxone [9-11]. In Senegal, studies have found high levels of resistance to tetracycline, cotrimoxazole, ampicillin, quinolones [12] and third-generation cephalosporins [13].

Bacterial resistance is a natural phenomenon [14]. However, it can be accelerated by the overuse of antibiotics in both human and veterinary medicine [1,15-17]. About $80 \%$ of antibiotics are used in community settings $[18,19]$. In developing countries, people can obtain them not only on prescription by exerting pressure on health workers but also on self-medication [1,18-21]. Low adherence to treatment is also recognized as a risk factor for bacterial resistance [3]. According to the WHO, many patients do not complete the prescribed treatment [17]. Misinformation, saving antibiotic for later, response to advertising are other factors contributing to bacterial resistance [22].

The latter is considered to be one of the greatest threats to human health [23]. Antimicrobial resistance, in particular antibiotic resistance, causes 700,000 deaths per year [1]. In the US, more than two million people are sickened every year with antibiotic-resistant infections. Of these, about 23,000 deaths are recorded every year. The loss of effective antibiotic treatments will compromise the treatment of most common bacterial diseases. It will also undermine the management of infectious complications in people with other diseases. For example, certain medical procedure such as joint replacements, organ transplants, cancer therapy could again become much more dangerous. In addition, chronic diseases such as diabetes, asthma would very difficult to treat [8]. Otherwise, according to the World Bank, antibiotic-resistant infections could hinder the achievement of sustainable development goals [24] and push 28 million people into poverty in 2050 [25].

Recognizing this alarming situation, WHO has developed a global action plan to prevent and control antimicrobial resistance [26]. This plan is structured around fives strategic objectives: (i) to improve awareness and understanding of antimicrobial resistance through effective communication, education and training; (ii) to strengthen the knowledge and evidence base through surveillance and research; (iii) to reduce the incidence of infection through effective sanitation, hygiene and infection prevention measures; (iv) to optimize the use of antimicrobial medicines in human and animal health; (v) to develop the economic case for sustainable investment that takes account of the needs of all countries and to increase investment in new medicines, diagnostic tools, vaccines and other interventions. Achieving these objectives requires the involvement of several stakeholders. Thus, the United Nations Food and Agriculture Program and the World Organization for Animal Health support this plan as part of 'One Health' approach to promote the rational use of antibiotics in human and animal health, agriculture and food chain [26]. According to this plan, understanding social science and behavior is also important for the achievement of objectives 1, 2, 3 and 4 [26].

In Senegal, a framework for fighting against bacterial resistance exists [27]. A multi-sectoral action plan against antimicrobial resistance is being finalized [28]. The country's ability to cope with bacterial resistance has been recently evaluated [29]. One of the main recommendations is the sensitization of the populations about antibiotics use [29]. However, understanding the knowledge level of populations 
about antibiotic use and bacterial resistance could better implement awareness campaigns. Thus, studies are conducted in several countries [30-32]. Ours fits in this dynamic. These studies found several misunderstanding about antibiotic use. For example, the respondents thought that they should stop taking antibiotics when they feel better [30]. They did not believe that they contribute to the development of bacterial resistance [31] and did not know that misuse of antibiotics can lead to bacterial resistance [32]. To the best of our knowledge, our study is the first in Senegal. It enriches global research on the general public's awareness about bacterial resistance. In addition, it will allow health authorities to make decisions and target awareness messages. Our goal was to evaluate the knowledge and opinions of the general public about antibiotic use and bacterial resistance.

\section{Materials and Methods}

\subsection{Study Setting}

The study took place in the Rufisque bus station. We selected this site for easy access to general public. It also saves cost and time. Rufisque is the departmental county town of the same name and belongs to the region of Dakar. It is subdivided into three district municipalities. In 2017, its population was estimated at 248.696 inhabitants [33]. City data are limited, but in the department, the average age of the population is 24 years old. Rates of education, literacy and unemployment are estimated at $75 \%$, $45 \%$ and $15.5 \%$, respectively. The average household size is 8.3 people. Promiscuity is a concern in the department since $15.7 \%$ of households have three people per residential room [34]. About $52 \%$ of households have a faucet in their dwelling, while $17.8 \%$ use the public tap or the standpipe [34]. In the department, only $19.7 \%$ of households have a specific place for washing hands with soap [35]. Sanitation is very little developed [36].

\subsection{Type and Period of Study}

We conducted a cross-sectional study of the general public's knowledge and opinions towards antibiotic use and bacterial resistance. The data collection took place from 25 November to 25 December 2017.

\subsection{Study Population}

The study population consisted of persons attending the Rufisque bus station. This included anyone over the age of 18 years, who had agreed to participate in the study and who was able to name one antibiotic. Health professionals such as doctors, nurses, midwives and pharmacists were excluded from the study.

\subsection{Sample Size}

We used the Raosoft sample size calculator [37] to estimate the sample size. The hypotheses were the following:

(i) response distribution: $50 \%$;

(ii) source population size: 20,000;

(iii) desired level of confidence: $95 \%$;

(iv) margin of error: $5 \%$.

In Senegal, there are no previously studies that assessed population's knowledge about antibiotic use and bacterial resistance. Therefore, we did not know the response distribution. We assumed that the response distribution for each question would be $50 \%$ using a margin of error of $5 \%$ and a confidence level of $95 \%$. These hypotheses maximize the sample size [37]. In addition, the source population size (people attending the bus station) was not known. According to Raosoft sample size calculator, we had set it at 20,000 [37]. Thus, the sample size was 377 . We rounded the size to 400 participants in order to optimize its representativeness. 


\subsection{Sampling Procedure}

For reasons of technical and financial feasibility, we performed a non-probability sampling (convenience sampling). Participants were recruited among the travelers encountered in front of the Rufisque bus station. Each person who rejected to participate in the study was replaced by another until the required number of subjects was reached. The participation was voluntary.

\subsection{Data Collection}

\subsubsection{Data Collection Instrument}

Our data collection instrument was a questionnaire which was developed by two co-authors. We did not perform the test-retest of the questionnaire. However, it was reviewed and improved by all co-authors, some of whom have an extensive experience in the area of public health, epidemiology and medicines. They have made relevant comments in both content and form. Some of the questions were reformulated while others were deleted. The questionnaire was also previously tested on 16 people. Then, we held a meeting with all the co-authors. Corrections were made based on feedbacks from the pre-test. The final version included a filter question to identify participant who are able to name one antibiotic. It consisted of four sections. The first was related to socio-demographic characteristics and included seven items. The second section assessed the level of knowledge through twelve questions while the sources of information were collected in the third section. Reponses on knowledge had three options: 'true', 'false' or 'don't know'. The correct option is 'false' for Q1-Q7 and 'true' for $\mathrm{Q} 8-\mathrm{Q} 12$. The incorrect option is 'true' or 'don't know' for Q 1-Q7 and 'false' or 'don't know' for $\mathrm{Q} 8-\mathrm{Q} 12$. The level of knowledge was evaluated as follows: One point was given for each correct answer and zero for each incorrect answer.

The overall score on knowledge was obtained by adding up the scores of the answers. The minimum and maximum scores were 0 and 12 points, respectively. The level of knowledge was classified according to the method described by Essi MJ and Njoya O [38]:

- "less than $25 \%$ of correct answers" = bad

- "more than or equal to $25 \%$ of correct answers and less than $50 \%$ of correct answers" = insufficient

- "more than or equal to $50 \%$ of correct answers and less than $70 \%$ of correct answers" = average

- "more than or equal to $70 \%$ of correct answers" = good

Finally, opinions towards antibiotic use and bacterial resistance were collected in the fourth section. This section consisted of four questions and the response options were 'yes', 'no' or 'no opinion'.

\subsubsection{Data Collection Method}

The data collection method used was a face-to-face interview conducted by one interviewer. The latter stood in front of the Rufisque bus station and questioned travelers who met the inclusion criteria. The interviewer was a sixth-year pharmacy student at the Cheikh Anta Diop University in Dakar, Senegal. He was trained within two days. The training consisted of sensitizing him about the context, rationale and objectives of the study. We presented him the data collection method and instrument. He was also trained in questionnaire administration before and after the pre-test.

\subsubsection{Data Collected}

The data collected were socio-demographic characteristics: age (18-30, 31-40, 41-50, 51-60, >60 years), sex (male/female), marital status (married/unmarried), professional status (employed/unemployed), education (yes/no), distance between place of residence and a health facility $(\leq 300 \mathrm{~m} />300 \mathrm{~m})$ and distance between place of residence and a community pharmacy $(\leq 300 \mathrm{~m} />300 \mathrm{~m})$.As for knowledge, the data were related to antibiotic use in colds/flu, sore throat, cough, diarrhea, fever and fatigue. Knowledge about risk factors for bacterial resistance, strategies 
to prevent bacterial resistance (hand washing, vaccination) and impact of antibiotic use in animals on human health was also collected. Finally, the participants' opinions on the levels of antibiotic consumption in the community, sensitization during consultation in health facilities or dispensing of medicines in pharmacies and their role in the fight against bacterial resistance were collected.

\subsection{Data Analysis}

The data was entered into Microsoft Excel 2010. The statistical analysis consisted of two parts. The first described the distribution of the variables. The qualitative variables were expressed as frequency and percentage. Knowledge score is expressed as mean \pm standard deviation. The second part was analytical. It studied the relationship between knowledge and sociodemographic variables. For this purpose, we performed a bivariate analysis ( $\chi^{2}$ test, OR with $95 \%$ confidence interval) and logistic regression. According to Hosmer DW and Lemeshow S, variables with $p$-value less than 0.25 in bivariate analysis were included in the logistic regression [39]. These authors show that use $p$-value of 0.05 as inclusion criteria for logistic regression model often fails to identify variables known to be important [39]. The significance level was 0.05.The analyzes were carried out using Epi Info 7.

\subsection{Ethical Considerations}

Our research involved human subjects. However, it was an observational study which was carried out as part of a Pharm. D thesis. We conducted this study in conditions that did not expose the participants to physical risks or discomfort (example: there was no blood test). It did not harm the environment either. The administration of the questionnaire lasted approximately $10 \mathrm{~min}$. Therefore, it did not irritate the participant.

All subjects gave their informed consent for inclusion before they participated in the study and after explaining the context, rationale and objectives of the study. Participation was voluntary. Each participant was informed that he or she had the opportunity to withdraw from the study at any time without being compelled to justify oneself. The data were collected anonymously and confidentially.

The Cheikh Anta Diop University Research Ethics Board approved this study.

\section{Results}

A total of 400 participants were included in our study. The questionnaire was administered to all 400 people $(100 \%)$ who agreed to participate in the survey. Only 22 persons rejected to participate because they were in a hurry. These persons were replaced by others who were readily available to the interviewer. All forms were completely filled (100\%).

\subsection{Socio-Demographic Characteristics}

The 31-40 age group was the most represented (32.5\%). It was followed by $18-30$ age group (28.5\%). People over the age of 60 accounted for $6.5 \%$ (Table 1).More than half of the participants were male (55\%) and married (55.5\%) (Table 1). Sixty-two percent (62\%) and nearly half of all participants $(48.75 \%)$ were employed and educated, respectively (Table 1).In addition, $49.25 \%$ and $68.5 \%$ lived in close proximity to a health facility and a community pharmacy, respectively (Table 1). 
Table 1. Socio-demographic characteristics' participants, Rufisque, Senegal, $2017(\mathrm{~N}=400)$.

\begin{tabular}{lcc}
\hline Socio-Demographic Characteristics & $\mathbf{n}$ & $\mathbf{\%}$ \\
\hline Age (years) & 114 & 28.5 \\
{$[18-30]$} & 130 & 32.5 \\
{$[31-40]$} & 87 & 21.8 \\
{$[41-50]$} & 43 & 10.8 \\
{$[51-60]$} & 26 & 6.5 \\
$>60$ & & \\
\hline Sex $\quad 220$ & 55 \\
Male & 180 & 45 \\
Female & & \\
\hline Marital status & 222 & 55.5 \\
Married & 178 & 44.5 \\
Unmarried & & 62 \\
\hline Professional status & 248 & 38 \\
Employed & 152 & \\
Unemployed & & 48.75 \\
\hline Education & 195 & 51.25 \\
Yes & 205 & 31.5 \\
$\quad$ No & & \\
\hline Close proximity to a health facility & 197 & 50.75 \\
Yes (<300 m) & 203 & \\
No (>300 m) & 274 & \\
\hline Close proximity to a community pharmacy & 126 & \\
Yes (<300 m) & & \\
No (>300 m) & & \\
\hline
\end{tabular}

\subsection{Filter Question}

All people included in the study cited one antibiotic. Among them, most mentioned amoxicillin (46\%) and sulfamethoxazole/trimethoprim (45\%) (Figure 1). Amoxicillin/clavulanic acid was indicated by $2 \%$ of respondents (Figure 1 ).

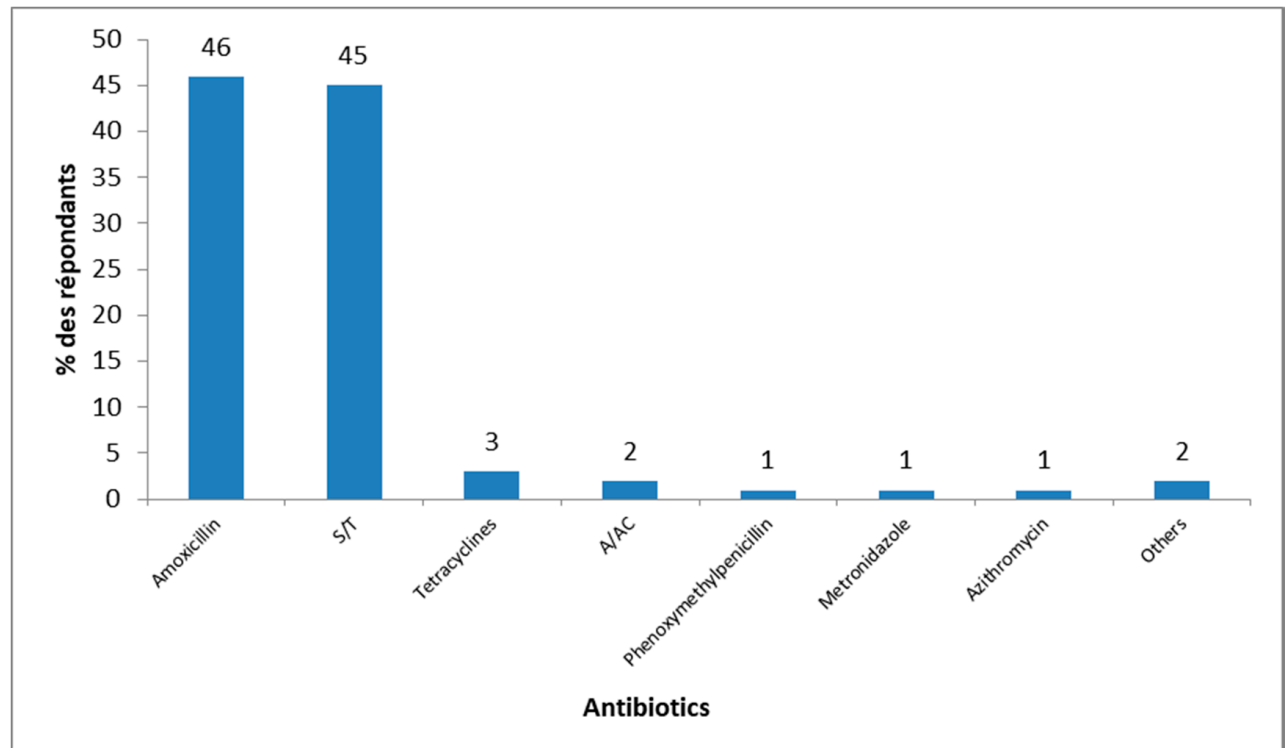

Figure 1. Antibiotic cited by participants, Rufisque, Senegal, $2017(\mathrm{~N}=400) . \mathrm{S} / \mathrm{T}=$ Sulfamethoxazole/Trimethoprim, A/AC = Amoxicillin/clavulanic acid, Others = Doxycycline, Gentamicin, Penicillins, Oxacillin. 


\subsection{Knowledge}

Most respondents mistakenly thought that antibiotics are effective against colds/flu (69.8\%), cough $(72.3 \%)$, and sore throat $(64.4 \%)$ (Table 2$)$. At the same time, $42.8 \%$ of surveyed participants said that one should stop taking an antibiotic treatment as soon as one feels better, while $83.8 \%$ knew that high antibiotic consumption can lead to bacterial resistance (Table 2).A quarter (25.5\%) of people was aware that poor patient compliance with antibiotic treatment can be harmful for people (Table 2). In addition, only $8.8 \%$ and $41.8 \%$ agreed that hand washing and vaccination can prevent bacterial resistance (Table 2).As for the excessive use of antibiotics in animals, $67.5 \%$ of the respondents thought that it has a negative impact on human health (Table 2).

Table 2. Participants' knowledge towards antibiotic use and bacterial resistance, Rufisque, Senegal, $2017(\mathrm{~N}=400)$.

\begin{tabular}{|c|c|c|c|}
\hline Statements & True n (\%) & False n (\%) & Don't Know n (\%) \\
\hline \multicolumn{4}{|l|}{ Antibiotics work against: } \\
\hline 1. Cold/Flu & $279(69.8)$ & $97(24.3)$ & $24(6.0)$ \\
\hline 2. Cough & $289(72.3)$ & $85(21.3)$ & $26(6.5)$ \\
\hline 3. Sore throat & $257(64.3)$ & $84(21.0)$ & $59(14.8)$ \\
\hline 4. Diarrhea & $141(35.3)$ & $184(46.0)$ & $75(18.8)$ \\
\hline 5. Fever & $167(41.8)$ & $205(51.3)$ & $28(7.0)$ \\
\hline 6. Fatigue & $203(50.8)$ & $153(38.3)$ & $44(11.0)$ \\
\hline $\begin{array}{l}\text { 7. One should stop taking an antibiotic treatment } \\
\text { as soon as one feels better }\end{array}$ & $171(42.8)$ & $227(56.8)$ & $2(0.5)$ \\
\hline $\begin{array}{l}\text { 8. High antibiotic consumption can lead to } \\
\text { bacterial resistance }\end{array}$ & $335(83.8)$ & $54(13.5)$ & $11(2.8)$ \\
\hline $\begin{array}{l}\text { 9. Poor patient compliance with antibiotic } \\
\text { treatment may be harmful to people }\end{array}$ & $102(25.5)$ & $267(66.8)$ & $31(7.8)$ \\
\hline 10. Handwashing can prevent bacterial resistance & $35(8.8)$ & $228(57)$ & $137(34.3)$ \\
\hline 11. Vaccination can prevent bacterial resistance & $167(41.8)$ & 205 (51.3) & $28(7)$ \\
\hline $\begin{array}{l}\text { 12. Inappropriate antibiotic use in animals can } \\
\text { result in negative impact on human health }\end{array}$ & $270(67.5)$ & $117(29.3)$ & $13(3.3)$ \\
\hline
\end{tabular}

Expected responses: False (Q1-Q7) and True (Q8-Q12).

\subsection{Knowledge Level Classification}

The average score was $4.5 \pm 1.96$. The highest score was 10 while the lowest was 0 . The mode was 4. The median, first quartile and third quartile were 4,3 and 6 , respectively. The level of knowledge was bad and insufficient in $58(14.5 \%)$ and $218(54.5 \%)$ participants, respectively. In contrast, only 96 (24\%) and $28(7 \%)$ had average and good level of knowledge, respectively. There were no significant associations between the respondents' socio-demographic characteristics and level of knowledge (Table 3).

Table 3. Bivariate and multivariate analysis of the relationship between good level of knowledge and socio-demographic characteristics, Rufisque, Senegal, 2017 ( $\mathrm{N}=400)$.

\begin{tabular}{ccccccccc}
\hline \multirow{2}{*}{ SDC } & \multicolumn{2}{c}{ GLN } & \multicolumn{1}{c}{ BA } & & MA \\
\cline { 2 - 8 } & Yes & No & OR & IC 95\% & $p$-Value & OR & IC 95\% & $p$-Value \\
\hline Age & 22 & 222 & 2.4 & {$[1.0-6.2]$} & 0.048 & 1.3 & {$[0.5-3.8]$} & 0.566 \\
$\leq 40$ & 6 & 150 & 1 & & & & & \\
$>40$ & 13 & 207 & 1 & & & & \\
\hline Sex & 15 & 165 & 1.45 & {$[0.67-3.13]$} & 0.344 & & & \\
Male & & & & & & & & \\
Female & 8 & 214 & 1 & & & & & \\
\hline MS & 20 & 158 & 3.39 & {$[1.46-7.89]$} & 0.003 & 2.5 & {$[0.9-6.6]$} & 0.056 \\
Married & & & & & & & & \\
Unmarried & &
\end{tabular}


Table 3. Cont.

\begin{tabular}{|c|c|c|c|c|c|c|c|c|}
\hline \multirow{2}{*}{ SDC } & \multicolumn{2}{|c|}{ GLN } & \multicolumn{3}{|c|}{ BA } & \multicolumn{3}{|c|}{ MA } \\
\hline & Yes & No & OR & IC $95 \%$ & $p$-Value & OR & IC $95 \%$ & $p$-Value \\
\hline \multicolumn{9}{|l|}{ Education } \\
\hline Yes & 20 & 175 & 2.81 & {$[1.21-6.54]$} & 0.012 & 6.4 & [0.8-48.1] & 0.073 \\
\hline No & 8 & 197 & 1 & & & & & \\
\hline \multicolumn{9}{|l|}{ PS } \\
\hline Employed & 13 & 235 & 1 & & & & & \\
\hline Unemployed & 15 & 137 & 1.98 & [0.91-4.28] & 0.078 & 1.3 & [0.6-2.9] & 0.563 \\
\hline \multicolumn{9}{|l|}{$\mathrm{CP}$ to $\mathrm{HF}$} \\
\hline Yes & 14 & 183 & 1.03 & [0.48-2.22] & 0.934 & & & \\
\hline No & 14 & 189 & 1 & & & & & \\
\hline \multicolumn{9}{|l|}{$\mathrm{CP}$ to $\mathrm{CP}$} \\
\hline Yes & 22 & 252 & 1.75 & [0.69-4.43] & 0.234 & 1.3 & {$[0.5-3.4]$} & 0.591 \\
\hline No & 6 & 120 & 1 & & & & & \\
\hline
\end{tabular}

SDC = Socio-demographic characteristics, GLN = Good level of knowledge, BA = Bivariate analysis, $\mathrm{MA}=$ Multivariate analysis, $\mathrm{CP}$ to $\mathrm{HF}=$ Close proximity to a health facility, $\mathrm{CP}$ to $\mathrm{CP}=$ Close proximity to a community pharmacy, MS = Marital status, PS = Professional status.

\subsection{Sources of Knowledge}

The top three sources of information cited by the respondents were entourage (family or friends) (58.5), pharmacy staff (54.5\%), doctor/nurse (25\%) (Figure 2). Television and radio were reported in $17 \%$ and $16.8 \%$, respectively (Figure 2 ).

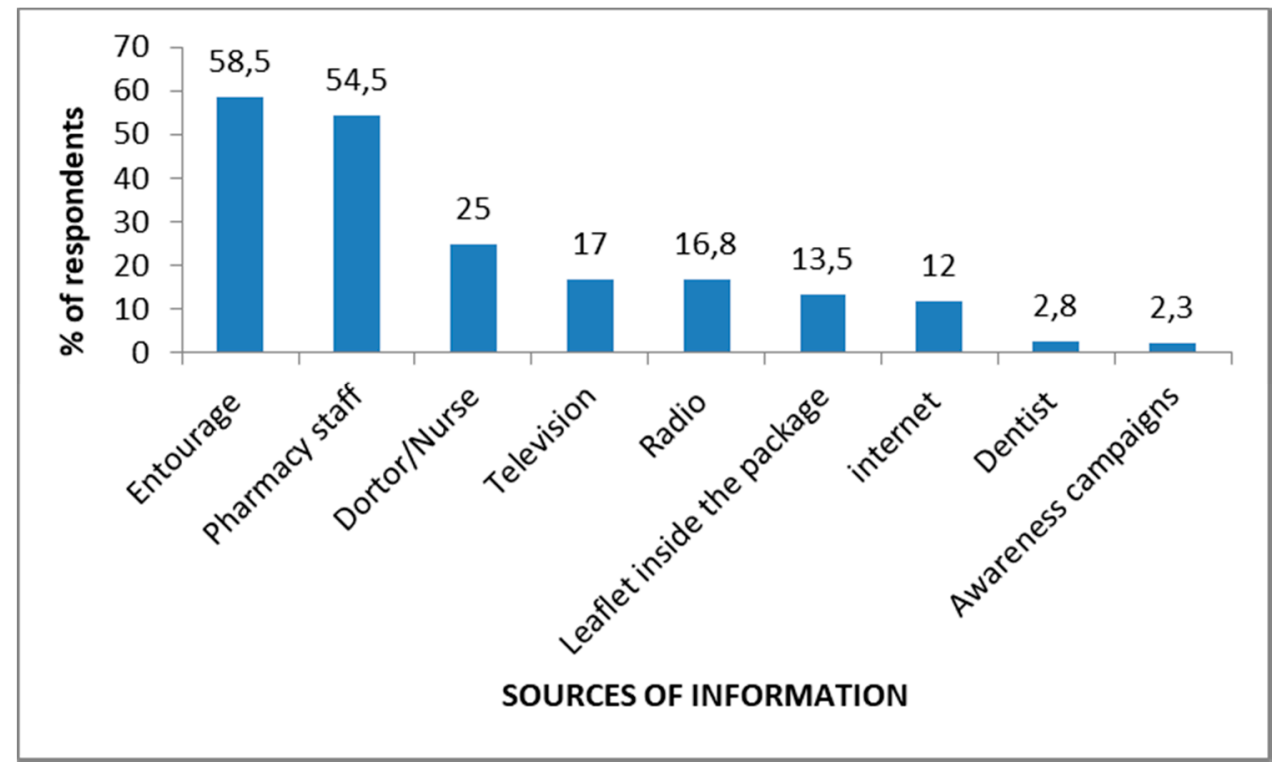

Figure 2. Sources of information, Rufisque, Senegal, $2017(\mathrm{~N}=400)$.

\subsection{Opinions}

Nearly eight out of ten people (78.3\%) thought that the population overuses antibiotics (Table 4 ). At the same time, $28 \%$ and $53.5 \%$ felt that they were not getting enough information about the consequences of poor adherence to antibiotic treatment, during consultations and dispensing, respectively (Table 4). About $45 \%$ of respondents thought that they do not have a large role to play in the fight against bacterial resistance (Table 4). 
Table 4. Participants' opinions towards antibiotic use and bacterial resistance, Rufisque, Senegal, 2017 $(\mathrm{N}=400)$.

\begin{tabular}{cccc}
\hline Statements & Yes, $\mathbf{n}(\%)$ & No, $\mathbf{n}(\%)$ & No Opinion, $\mathbf{n}(\%)$ \\
\hline Do you think that the population overuses antibiotics? & $313(78.3)$ & $26(6,5)$ & $61(15.3)$ \\
\hline $\begin{array}{c}\text { Do you think we give you enough information, during the } \\
\text { consultations, about antibiotics regarding their } \\
\text { ineffectiveness if they are misused? }\end{array}$ & $112(28)$ & $278(69.5)$ & $10(2.5)$ \\
\hline $\begin{array}{c}\text { Do you think we give you enough information, during the } \\
\text { dispensation, about antibiotics regarding their } \\
\text { ineffectiveness if they are misused? }\end{array}$ & $214(53.5)$ & $181(45.3)$ & $5(1.3)$ \\
\hline $\begin{array}{c}\text { Do you think you can play a big role in fighting } \\
\text { bacterial resistance? }\end{array}$ & $183(45.8)$ & $112(28)$ & $105(26.3)$ \\
\hline
\end{tabular}

\section{Discussion}

We aimed to assess the general public's knowledge and opinions about antibiotic use and bacterial resistance in an urban setting.

Our study showed that the two most cited antibiotics were amoxicillin (46\%) and sulfamethoxazole/trimethoprim (45\%). In a study conducted in Kenya, they were also the most mentioned by participants [40]. These results assume that the population is accustomed to using these two broad-spectrum antibiotics. They are among the most accessible antibiotics in Africa [40]. Studies conducted in Senegal and Angola seem to confirm our hypothesis since amoxicillin and sulfamethoxazole/trimethoprim were among the most common antibiotics found in households [41,42]. The use of broad-spectrum antibiotics can lead to an intestinal flora imbalance and the spread of bacterial resistance [43]. In Senegal, cases of bacterial resistance against sulfamethoxazole/trimethoprim were reported in patients with community-acquired urinary tract infection [44]. So these antibiotics should be used carefully. Further studies should be conducted in order to understand the reasons underlying the familiarity of the population with these two antibiotics.

This study has shown many misconceptions about antibiotic use. Indeed, more than three out of five people wrongly thought that antibiotics work against cough (72.3\%), colds/flu (69.8\%), sore throat $(64.3 \%)$ and diarrhea $(35.3 \%)$. Similar results were found in a WHO study conducted in several countries [30]. According to this study, $64 \%$ and $70 \%$ of respondents thought that antibiotics have an effect against colds / flu and sore throat [30], respectively. In Saudi Arabia, 66.4\% of the population thought that antibiotics are effective against colds or coughs [45]. In most cases, these infections are of viral origin [46-49]. Antibiotics are not routinely recommended as they cannot kill viruses [46-48]. These misconceptions may be due to the propensity of health professionals to prescribe or dispense antibiotics against these diseases witch are self-limiting $[45,50]$. According to Pelluchi et al., prescribers use antibiotics to prevent complications, relieve symptoms or satisfy patient's desires [46]. For example, in the United States, nearly $68 \%$ of patients with respiratory infections are unnecessarily treated with antibiotics [1]. The misunderstanding about antibiotic use clearly demonstrates the need to sensitize populations on the proven efficacy of analgesics against acute respiratory infections [46]. This awareness is fundamental because the unnecessary antibiotic use exposes them to side effects such as diarrhea, vomiting and rash, bacterial flora imbalance and bacterial resistance [46]. Additionally, continuing education for health professionals on rational use of antibiotics would be necessary. This training should be an opportunity to encourage them not only to resist against patient pressure but also to prescribe laboratory diagnosis in order to identify the germ.

In our study, $42.8 \%$ of respondents incorrectly supported the idea that antibiotic treatment should be discontinued as soon as symptoms disappear. This proportion was comparable to those found in Angola (40\%) [51] and Malaysia (41.9\%) [52], but lower than those found in Kenya (83.6\%; 93.4\%) [40] and India (65.55\%) [53]. The lack of knowledge about antibiotic use could concretely result in the arbitrary cessation of treatment. For example, in the United Kingdom and Ethiopia, patients admitted 
to having stopped treatment as soon as they felt better [3,54]. This inadequate practice exposes them to the risk of recurrence and bacterial resistance [53].

Overuse of antibiotics is a risk factor for bacterial resistance. This relationship is widely mentioned in the literature $[3,55,56]$. In our study, almost five out of six people $(83.8 \%)$ recognized it. This proportion was comparable to that found in Romania (87\%) [57], while it was higher than those found in Malaysia (59.1\%) [58], in Egypt (60.7\%) [59], in Namibia (72\%) [60], and in a systematic review $(70 \%)$ [32]. On the one hand, overuse of antibiotics could result from inappropriate prescriptions which are very common in sub-Saharan Africa $[3,61]$. On the other hand, it could be interpreted as a consequence of self-medication which itself is exacerbated by the sale of drugs, including antibiotics, 'over-the-counter' [1,3,62]. In West Africa, antibiotics can even be obtained in popular markets [63]. Solutions to reduce unnecessary use of antibiotic exist. It includes public education [3], on-going in-service education for prescribers especially those with a short experience [64] and regulation of the pharmaceutical sector [65].

In our study, few people $(25.5 \%)$ knew that poor patient compliance with antibiotic treatment may be harmful to people. Indeed, it can lead to resistant strains which can spread across borders [66]. The transmission is favored by poverty, which is a characteristic of developing countries [66]. In fact, poor people have limited access to care services [66]. Thus, they represent sources of transmission when they suffer from communicable diseases [66]. Considering poor patient compliance as a personal problem demonstrates clearly that the general public is not well aware of the risk factors and extent of bacterial resistance.

Nearly $68 \%$ of respondents agreed that the inappropriate use of antibiotics in animals can have a negative impact on human health. Most antibiotics used in animals belong to the same classes of antimicrobials used in human medicine $[17,67]$. In some African countries, including Senegal, more than $80 \%$ of animal products contain drug residues [68]. The use of these antibiotics for the promotion of growth, generally at low doses, is a risk factor for bacterial resistance [17]. The resistant strains found in animal productions can be transmitted to humans through the food chain and compromise the efficacy of antimicrobials in human medicine [69]. Therefore, the consideration of agricultural and livestock sectors in the prevention and control of bacterial resistance is essential. The 'one health' approach is a great opportunity to promote the rational use of antibiotics in humans and animals.

The results of our study revealed that only $8.8 \%$ and $41.8 \%$ of surveyed participants recognized that regular hand washing with soap and vaccination can prevent bacterial resistance, respectively. However, these two strategies avoid contracting infectious diseases. So they reduce the need for antibiotics. For example, several studies have shown that the pneumococcal vaccine has reduced antibiotic resistance in both children and adults [70,71]. As for the hand washing, it is admitted that it diminish the occurrence of diarrheal and respiratory diseases [72]. These results show that the fight against bacterial resistance necessarily involves sensitizing the populations in order to make them understand the importance of these two high-impact strategies. However, while hand washing is an easily achievable practice, the major challenge for Africa remains the availability and accessibility of vaccines.

Overall, almost three people (69\%) out of four had bad or insufficient level of knowledge toward antibiotic use and bacterial resistance. This situation is comparable to that found in Kuwait (47\%) [73], Lithuania (61.1\%) [74] and Egypt (59.6\%) [59]. In addition, our study did not reveal a significant relationship between the good level of knowledge and socio-demographic characteristics. However, other studies have shown the influence of sex, age [75] and level of education [74,75] on knowledge. In our study, the non-significant association between socio-demographic characteristics and the good level of knowledge could be explained by the fact that we used a non-probability sampling technique. Further studies are needed in order to identify the socio-demographic determinants of the knowledge regarding antibiotic use and bacterial resistance. 
The main sources of information identified in this study were the entourage (58.5\%), the pharmacy staff (54.5\%) and the Doctors/nurses (25\%). These three sources of information were mostly identified in Kenya [40] and Lithuania [74]. In contrast, awareness campaigns were reported by a small proportion of respondents $(2.3 \%)$. Our study showed that health authorities should set up and intensify training and awareness programs for health professionals so that they can enhance people's knowledge through reliable information. Moreover, about $17 \%, 16.8 \%$ and $12 \%$ of respondents cited television, radio and internet as sources of information, respectively. These results showed that information on antibiotic use is not widely disseminated in these communication media despite their strong presence in households and among young people. However, the effectiveness of awareness campaigns disseminated through television is proven in several countries [31].

Most (78.3\%) of surveyed participants believed that the population overuses antibiotics. A recent study corroborates this view. It shows that global consumption of antibiotics increased by $65 \%$ between 2000 and 2015 [76]. This increase is stronger in developing countries [76]. Awareness of our study population about high rate of antibiotic consumption is an opportunity to encourage the community to use antibiotics only when they are needed. This would allow us to preserve the effectiveness of the current therapeutic arsenal. Hence, the post-antibiotic era so feared could not come to pass.

Paradoxically, $28 \%$ of the participants believed that they do not have a great role to play in fighting bacterial resistance. A similar opinion was found in a recent study in which adolescents thought that solving the problem of bacterial resistance is the responsibility of prescribers [77]. The WHO survey found that $57 \%$ of respondents though they cannot do much to stop bacterial resistance [30]. This shows that the population has not been aware of the actions they could initiate against bacterial resistance. WHO has identified five relevant actions [78]:

- 'Only use antibiotics when prescribed by a certified health professional'

- 'Always take the full prescription, even if you feel better'

- 'Never use left-over antibiotics'

- 'Never share antibiotics with others'

- 'Prevent infections by regularly washing your hands, avoiding close contact with sick people and keeping your vaccinations up to date'

But, it would be necessary to multiply the awareness campaigns for a strict application of these five recommendations.

Furthermore, communication between patients and healthcare professionals is essential to combat bacterial resistance. In this study, only $28 \%$ of people thought that they did not receive enough information about bacterial resistance during consultation in health facilities. This could be due to a lack of knowledge among prescribers who, in some countries such as Ghana, face limited access to the internet, lack of information on the patterns of resistance [79]. In addition, $45.8 \%$ of participants felt that they receive enough information from pharmacy staff. This proves that pharmacists have a very important role in the fight against bacterial resistance given their proximity to populations. However, to assume this role, the pharmacist needs to update his knowledge in accordance with the 'Seven-Star Pharmacist concept' [80]. To this end, the health authorities should collaborate with pharmacists in order to set up a continuing education program on bacterial resistance.

Our study has two limitations. First, the sampling is non-probabilistic. According to Bornstein $\mathrm{MH}$ et al., in this type of sampling, participants were selected because they are easily accessible [81]. In this study, the sample consisted of individuals attending the Rufisque bus station. So, there was a low chance to include some persons such as those who have their own car. Therefore, the sample is not representative of the entire population. Second, the survey was limited to an urban area. In general, socio-economic status may be different between urban and rural areas. Consequently, people's knowledge and perceptions towards antibiotic use and bacterial resistance may vary according to area of residence. In the light of these considerations, our results would not generalizable. However, 
to the best of our knowledge, this is the first study in Senegal. Thus, it is a starting point for further research that focuses both on urban and rural settings using a probability sampling.

\section{Conclusions}

Our study showed a weak knowledge and misconceptions about antibiotic use and bacterial resistance among people living in an urban setting. Therefore, sensitizing the general public is necessary. Health professionals should regularly undergo continuing education sessions so that they can provide reliable information to patients. Conducting further studies on practices and attitudes towards antibiotic use would help to better target the awareness campaigns and training.

Author Contributions: The following statements should be used "Conceptualization, O.B. and D.F.; Methodology, O.B.; Data collection, M.M.; Writing: Original Draft Preparation, O.B.; Writing: Review and Editing, O.B., N.M.S., M.D., M.M.M.L., M.M., D.F., I.S., A.F. and A.T.-D.; Supervision, I.S., A.F., D.F. and A.T.-D. All the authors approved the final manuscript.

Funding: This research received no external funding.

Acknowledgments: We sincerely thank the residents of Rufisque who accepted to participate in this study. Also, we thank Hilaire Sarr who entered and analyzed the data.

Conflicts of Interest: The authors declare no conflict of interest.

\section{References}

1. O'Neill, J. Tackling Drug-Resistant Infections Globally: Final Report and Recommendations. Review on Antimicrobial Resistance. Wellcome Trust and HM Government 2016. Available online: https: / / amr-review. org/sites/default/files/160525_Final\%20paper_with\%20cover.pdf (accessed on 10-May 2018).

2. Martínez, J.L.; Baquero, F. Emergence and spread of antibiotic resistance: Setting a parameter space. Upsal. J. Med. Sci. 2014, 119, 68-77. [CrossRef] [PubMed]

3. Zaman, S.B.; Hussain, M.A.; Nye, R.; Mehta, V.; Mamun, K.T.; Hossain, N. A Review on Antibiotic Resistance: Alarm Bells are Ringing. Cureus 2017, 9, e1403. [CrossRef] [PubMed]

4. Davies, J.; Davies, D. Origins and evolution of antibiotic resistance. Microbiol. Mol. Biol. Rev. 2010, 74, 417-433. [CrossRef] [PubMed]

5. World Health Organization. Antimicrobial Resistance: Global Report on Surveillance; WHO: Geneva, Switzerland, 2014. Available online: http://apps.who.int/iris/bitstream/handle/10665/112642/ 9789241564748_eng.pdf;jsessionid=5290CC8F73C7B46FDD0DD9FB65AC549F? sequence=1 (accessed on 10 May 2018).

6. Organisation Mondiale de la Santé. Plus Sain, Plus Juste, Plus sûr: L'itinéraire de la Santé Dans le Monde, 2007-2017; OMS: Geneve, Switzerland, 2017. Available online: http://apps.who.int/iris/bitstream/handle/ 10665/259203/9789242512366-fre.pdf?sequence=1\&isAllowed=y (accessed on 3 July 2018).

7. Australian Government. Australia's First National Antimicrobial Resistance Strategy 2015-2019; Progress Report; Australian Government: Canberra, Australia, 2017. Available online: https:/ /www.amr.gov.au/resources/ australias-first-national-antimicrobial-resistance-strategy-2015-2019-progress-report (accessed on 3 July 2018).

8. Centers for Diseases Control and Prevention. Antibiotic Resistance Threats in the United States. 2013. Available online: https:/ / www.cdc.gov/drugresistance/pdf/ar-threats-2013-508.pdf (accessed on 25 June 2018).

9. Tadesse, B.T.; Ashley, E.A.; Ongarello, S.; Havumaki, J.; Wijegoonewardena, M.; González, I.J.; Dittrich, S. Antimicrobial resistance in Africa: A systematic review. BMC Infect. Dis. 2017, 17, 616. [CrossRef] [PubMed]

10. Ampaire, L.; Muhindo, A.; Orikiriza, P.; Mwanga-Amumpaire, J.; Bebell, L.; Boum, Y. A review of antimicrobial resistance in East Africa. Afr. J. Lab. Med. 2016, 5, 432. [CrossRef] [PubMed]

11. Bernabé, K.J.; Langendorf, C.; Ford, N.; Ronat, J.B.; Murphy, R.A. Antimicrobial resistance in West Africa: A systematic review and meta-analysis. Int. J. Antimicrob. Agents 2017, 50, 629-639. [CrossRef] [PubMed]

12. Sambe-Ba, B.; Seck, A.; Wane, A.A.; Fall-Niang, N.K.; Gassama-Sow, A. Sensibilité aux antibiotiques et supports génétiques de la résistance des souches de Shigella flexneri isolées à Dakar de 2001 à 2010. Bull. Soc. Pathol. Exot. 2013, 106, 89-94. [CrossRef] [PubMed] 
13. Breurec, S.; Bouchiat, C.; Sire, J.; Moquet, O.; Bercion, R.; Cisse, M.F.; Seck, A. High third-generationcephalosporin resistant Enterobacteriaceae prevalence rate among neonatal infections in Dakar, Senegal. BMC Infect. Dis. 2016, 16, 587. [CrossRef] [PubMed]

14. A Global Declaration on Appropriate Use of Antimicrobial Agents across the Surgical Pathway. Available online: https: / / www.ncbi.nlm.nih.gov/pubmed/29173054 (accessed on 9 August 2018).

15. Salm, F.; Ernsting, C.; Kuhlmey, A.; Kanzler, M.; Gastmeier, P.; Gellert, P. Antibiotic use, knowledge and health literacy among the general population in Berlin, Germany and its surrounding rural areas. PLoS ONE 2018, 13, e0193336. [CrossRef] [PubMed]

16. Smith, D.R.M.; Dolk, F.C.K.; Pouwels, K.B.; Christie, M.; Robotham, J.V.; Smieszek, T. Defining the appropriateness and inappropriateness of antibiotic prescribing in primary care. J. Antimicrob. Chemother. 2018, 73, ii11-ii18. [CrossRef] [PubMed]

17. Lee, C.R.; Cho, I.H.; Jeong, B.C.; Lee, S.H. Strategies to minimize antibiotic resistance. Int. J. Environ. Res. Public Health 2013, 10, 4274-4305. [CrossRef] [PubMed]

18. Kotwani, A.; Holloway, K. Trends in antibiotic use among outpatients in New Delhi, India. BMC Infect. Dis. 2011, 11, 99. [CrossRef] [PubMed]

19. Chem, E.D.; Anong, D.N.; Akoachere, J.K.T. Prescribing patterns and associated factors of antibiotic prescription in primary health care facilities of Kumbo East and Kumbo West Health Districts, North West Cameroon. PLoS ONE 2018, 13, e0193353. [CrossRef] [PubMed]

20. Organisation Mondiale de la Santé. Rapport Sur la Santé Dans le Monde. Plus de Santé Pour Son Argent; OMS: Généve, Switzerland, 2010. Available online: http:/ / apps.who.int/iris/bitstream/handle/10665/44372/ 9789242564020_fre.pdf?sequence=1 (accessed on 10 October 2017).

21. Massele, A.; Tiroyakgosi, C.; Matome, M.; Desta, A.; Muller, A.; Paramadhas, B.D.A.; Godman, B. Research activities to improve the utilization of antibiotics in Africa. Expert Rev. Pharmacoecon. Outcomes Res. 2017, 17, 1-4. [CrossRef] [PubMed]

22. Donyai, P.; Okafor, S.; Virgo, R.; Amin, K.; Nasr, M. Messages about Antibiotic Resistance in Different Newspaper Genres. Pharmacy 2013, 1, 181-192. [CrossRef]

23. Bonten, M.J.; Austin, D.J.; Lipsitch, M. Understanding the spread of antibiotic resistant pathogens in hospitals: Mathematical models as tools for control. Clin. Infect. Dis. 2001, 33, 1739-1746. [CrossRef] [PubMed]

24. World Bank Group. Drug-Resistant Infections: A Threat to Our Economic Future; Final Report; WBG: Washington, DC, USA, 2017. Available online: http://documents.worldbank.org/curated/en/ 323311493396993758/pdf/114679-REVISED-v2-Drug-Resistant-Infections-Final-Report.pdf (accessed on 10 October 2017).

25. World Bank Group. Communiqués de Presse; WBG: Washington, DC, USA, 2016. Available online: http:/ / www.banquemondiale.org/fr/news/press-release/2016/09/18/by-2050-drug-resistant-infectionscould-cause-global-economic-damage-on-par-with-2008-financial-crisis (accessed on 10 October 2017).

26. Organisation Mondiale de la Santé. Plan D'action Mondial Pour Combattre la Résistance Aux Antimicrobiens; OMS: Généve, Switzerland, 2016. Available online: http://apps.who.int/iris/bitstream/handle/10665/ 249548/9789242509762fre.pdf;jsessionid=6BA7B094CA69BC758FC52F00A7E179E0?sequence=1 (accessed on 20 January 2018).

27. Coll-Seck, A.M.; Seck, I.; Sow, A.I.; Ndoye, B.; Ngom, B.; Diack, P.A. La gouvernance contre la résistance aux antimicrobiens en Afrique: Faire face quand les ressources sont limitées—L'exemple du sénégal. In $A M R$ Control. Surmonter La Résistance Aux Antimicrobiens, 3rd ed.; WAAAR; Global Health Dynamics: Suffolk, UK, 2017; Volume 1, pp. 10-15. ISBN 978-0-9576072-7-9. Available online: http://view.pagetiger.com/AMR/ AMR2018/PDF.pdf (accessed on 10 January 2018).

28. Ministère du commerce. Du sectuer informel. De la consommation, de la promotion des produits locaux et des petites et moyennes entreprises. In Santé et Sécurité Sanitaire des Aliments; Ministère du commerce: Dakar, Senegal, 2018. Available online: http:/ / www.commerce.gouv.sn/article.php3?id_article=503\#sthash. JHrOiFPf.BuhJMRZj.dpbs (accessed on 16 May 2018).

29. Organisation Mondiale de la santé. Évaluation Externe Conjointe des Principales Capacités RSI de la Republique du Senegal; Rapport de Mission: 28 Novembre-2 Décembre 2016; OMS: Généve, Switzerland, 2017. Available online: http:/ / apps.who.int/iris/bitstream/handle/10665/255765/WHO-WHE-CPI-2017.31-fre. pdf? sequence $=1$ (accessed on 20 January 2018). 
30. World Health Organization. Antibiotic Resistance: Multi-Country Public Awareness Survey; WHO: Généve, Switzerland, 2015. Available online: http:/ / apps.who.int/iris/bitstream/handle/10665/194460/ 9789241509817_eng.pdf?sequence=1\&isAllowed=y (accessed on 20 January 2018).

31. Gualano, M.R.; Gili, R.; Scaioli, G.; Bert, F.; Siliquini, R. General population's knowledge and attitudes about antibiotics: A systematic review and meta-analysis. Pharmacoepidemiol. Drug Saf. 2015, 24, 2-10. [CrossRef] [PubMed]

32. McCullough, A.R.; Parekh, S.; Rathbone, J.; Del Mar, C.B.; Hoffmann, T.C. A systematic review of the public's knowledge and beliefs about antibiotic resistance. J. Antimicrob. Chemother. 2016, 71, 27-33. [CrossRef] [PubMed]

33. Agence Nationale de la Statistique et de la Démographie. Projection de la Population de la Region de Dakar, 2013-2025; ANSD: Dakar, Senegal, 2013. Available online: http:/ /www.ansd.sn/ressources/publications / indicateurs/Projections-demographiques-2013-2025+.htm (accessed on 16 May 2018).

34. Agence Nationale de la Statistique et de la Démographie. Recensement Général de la Population et de l'Habitat, de l'Agriculture et de l'Elevage; Rapport Régional Définitif; ANSD: Dakar, Senegal, 2017. Available online: http:/ / www.ansd.sn/ressources/RGPHAE-2013/ressources/doc/pdf/RGPHAERapport-regional_DAKAR_vf.pdf (accessed on 17 May 2018).

35. Agence Nationale de la Statistique et de la Démographie et Fonds des Nations Unies pour l'enfance. MICS V Dakar Enquête par Grappes à Indicateurs Multiples 2015-2016; Rapport Final; ANSD: Dakar, Sénégal, 2016. Available online: http:/ / www.ansd.sn/ressources/publications/RAPPORT\%20MICS\%20Urbaine\% 20Dakar\%202015-2016_FINAL\%20novembre_version\%20finale\%20.pdf (accessed on 17 May 2018).

36. Office National de L'assainissement $d u$; ONAS: Dakar, Sénégal, 2018. Available online: https: //www.onas.sn/onas/actualites/actualites-onas/probleme-dassainissement-a-rufisque-le-ministere-delhydraulique-et-de (accessed on 16 May 2018).

37. Raosoft, Inc. Raosoft Sample Size Calculator. 2004. Available online: http:/ / www.raosoft.com/samplesize. html (accessed on 30 October 2017).

38. José, E.M.; Oudou, N. L'enquête CAP (Connaissances, Attitudes, Pratiques) en recherche médicale. Health Sci. Dis. 2013, 14, 1-3.

39. Hosmer, D.W.J.; Lemeshow, S. Applied Logistic Regression, 2nd ed.; Wiley-Interscience Publication: New York, NY, USA, 2000; p. 392.

40. Omulo, S.; Thumbi, S.M.; Lockwood, S.; Verani, J.R.; Bigogo, G.; Masyongo, G.; Call, D.R. Evidence of superficial knowledge regarding antibiotics and their use: Results of two cross-sectional surveys in an urban informal settlement in Kenya. PLoS ONE 2017, 12, e0185827. [CrossRef] [PubMed]

41. Padget, M.; Tamarelle, J.; Herindrainy, P.; Ndir, A.; Diene Sarr, F.; Richard, V.; BIRDY Study Group. A community survey of antibiotic consumption among children in Madagascar and Senegal: The importance of healthcare access and care quality. J. Antimicrob. Chemother. 2017, 72, 564-573. [CrossRef] [PubMed]

42. Ocan, M.; Bbosa, G.S.; Waako, P.; Ogwal-Okeng, J.; Obua, C. Factors predicting home storage of medicines in Northern Uganda. BMC Public Health. 2014, 14, 650. [CrossRef] [PubMed]

43. Spaulding, C.N.; Klein, R.D.; Schreiber, H.L.; Janetka, J.W.; Hultgren, S.J. Precision antimicrobial therapeutics: The path of least resistance? NPJ Biofilms Microbiomes 2018, 4, 4. [CrossRef] [PubMed]

44. Barry, M.S.; Diallo, B.A.; Kanté, D.; Diallo, I.S. Antimicrobial susceptibility profile of community-acquired urinary tract infection in adults: A seven months prospective cross-sectional study in Dakar Town, Senegal. Afr. J. Urol. 2017, 23, 166-171. [CrossRef]

45. Abujheisha, K.Y.; Al-Shdefat, R.; Ahmed, N.; Fouda, M.I. Public Knowledge and Behaviours Regarding Antibiotics Use: A Survey among the General Public. Int. J. Med. Res. Health Sci. 2017, 6, 82-88.

46. ESCMID Sore Throat Guideline Group; Pelucchi, C.; Grigoryan, L.; Galeone, C.; Esposito, S.; Huovinen, P.; Little, P.; Verheij, T. Guideline for the management of acute sore throat. Clin. Microbiol. Infect. 2012, 18, 1-28. [CrossRef] [PubMed]

47. Hersh, A.L.; Jackson, M.A.; Hicks, L.A.; American Academy of Pediatrics Committee on Infectious Diseases. Principles of judicious antibiotic prescribing for upper respiratory tract infections in pediatrics. Pediatrics 2013, 132, 1146-1154. [CrossRef] [PubMed]

48. Riddle, M.S.; DuPont, H.L.; Connor, B.A. ACG Clinical Guideline: Diagnosis, Treatment, and Prevention of Acute Diarrheal Infections in Adults. Am. J. Gastroenterol. 2016, 111, 602-622. [CrossRef] [PubMed] 
49. Eilat-Tsanani, S.; Tabenkin, H.; Chazan, B.; Lavi, I.; Cwikel-Hamzany, S. Acute cough: The use of antibiotics and health care services in an urban health centre in Israel. Eur. J. Gen. Pract. 2013, 19, 92-98. [CrossRef] [PubMed]

50. Hassali, M.A.; Arief, M.; Saleem, F.; Khan, M.U.; Ahmad, A.; Mariam, W.; Bheemavarapu, H.; Syed, I.A. Assessment of attitudes and practices of young Malaysian adults about antibiotics use: A cross-sectional study. Pharm. Pract. (Granada) 2017, 15, 929. [CrossRef] [PubMed]

51. Cortez, J.; Rosário, E.; Pires, J.E.; Taborda Lopes, J.; Francisco, M.; Vlieghe, E.; Brito, M. Antimicrobial storage and antibiotic knowledge in the community: A cross-sectional pilot study in north-western Angola. Int. J. Infect. Dis. 2017, 60, 83-87. [CrossRef] [PubMed]

52. Lim, K.K.; Teh, C.C. A Cross Sectional Study of Public Knowledge and Attitude towards Antibiotics in Putrajaya, Malaysia. South. Med. Rev. 2012, 5, 26-33. [PubMed]

53. Chandrakanth, P.; Mohamed Saleem, T.S.; Madhan Mohan, R.; Gopinath, C.; Madhan Mohan, R. Assessment of public knowledge and attitude regarding antibiotic use in a tertiary care hospital. Asian J. Pharm. Clin. Res. 2016, 9, 118-122.

54. Gebeyehu, E.; Bantie, L.; Azage, M. Inappropriate Use of Antibiotics and Its Associated Factors among Urban and Rural Communities of Bahir Dar City Administration, Northwest Ethiopia. PLoS ONE 2015, 10, e0138179. [CrossRef] [PubMed]

55. Friedman, B.C.; Schwabe-Warf, D.; Goldman, R. Reducing inappropriate antibiotic use among children with influenza infection. Can. Fam. Phys. 2011, 57, 42-44.

56. Truter, I. Antimicrobial prescribing in South Africa using a large pharmacy database: A drug utilisation study. South Afr. J. Infect. Dis. 2015, 30, 52-56. [CrossRef]

57. Topor, G.; Grosu, I.A.; Ghiciuc, C.M.; Strat, A.L.; Lupuşoru, C.E. Awareness about antibiotic resistance in a self-medication user group from Eastern Romania: A pilot study. Peer] 2017, 5, e3803. [CrossRef] [PubMed]

58. Oh, A.L.; Hassali, M.A.; Al-haddad, M.S.; Azhar, S.; Sulaiman, S. Original Article Public knowledge and attitudes towards antibiotic usage: A cross-sectional study among the general public in the state of Penang, Malaysia. J. Infect. Dev. Ctries. 2010, 5, 338-347.

59. Awadh, A.M.; Raja, A.K.; Mahdi, A.I.; Khalid, A.A. Assessment of Knowledge, Attitude and Practice Regarding Antibiotics Misuse among the Public in Saudi Arabia. Egypt. J. Hosp. Med. 2017, 69, 2405-2411. [CrossRef]

60. Pereko, D.D.; Lubbe, M.S.; Essack, S.Y. Public knowledge, attitudes and behaviour towards antibiotic usage in Windhoek, Namibia Public knowledge, attitudes and behaviour towards antibiotic usage in Windhoek, Namibia. S. Afr. J. Infect. Dis. 2015, 30, 134-137. [CrossRef]

61. Holloway, K.A.; Ivanovska, V.; Wagner, A.K.; Vialle-Valentin, C.; Ross-Degnan, D. Have we improved use of medicines in developing and transitional countries and do we know how to? Two decades of evidence. Trop. Med. Int. Health 2013, 18, 656-664. [CrossRef] [PubMed]

62. Ayalew, M.B. Self-medication practice in Ethiopia: A systematic review. Patient Prefer Adherence 2017, 11, 401-413. [CrossRef] [PubMed]

63. Ouedraogo, A.S.; Jean Pierre, H.; Bañuls, A.L.; Ouédraogo, R.; Godreuil, S. Émergence et diffusion de la résistance aux antibiotiques en Afrique de l'Ouest: Facteurs favorisants et évaluation de la menace. Med. Sante Trop. 2017, 27, 147-154. [CrossRef] [PubMed]

64. Labi, A.K.; Obeng-Nkrumah, N.; Bjerrum, S.; Aryee, N.A.A.; Ofori-Adjei, Y.A.; Yawson, A.E.; Newman, M.J. Physicians' knowledge, attitudes, and perceptions concerning antibiotic resistance: A survey in a Ghanaian tertiary care hospital. BMC Health Serv. Res. 2018, 18, 126. [CrossRef] [PubMed]

65. Ahiabu, M.A.; Magnussen, P.; Bygbjerg, I.C.; Tersbøl, B.P. Treatment practices of households and antibiotic dispensing in medicine outlets in developing countries: The case of Ghana. Res. Social Adm. Pharm. 2018, 7, 29428578. [CrossRef] [PubMed]

66. Komolafe, O.O. Antibiotic resistance in bacteria-An emerging public health problem. Malawi Med. J. 2003, 15, 63-67. [CrossRef] [PubMed]

67. Mutua, J.M.; Gitao, C.G.; Bebora, L.C.; Mutua, F.K. Antimicrobial Resistance Profiles of Bacteria Isolated from the Nasal Cavity of Camels in Samburu, Nakuru, and Isiolo Counties of Kenya. J. Vet. Med. 2017, 2017, 1216283. [CrossRef] [PubMed] 
68. Nadimpalli, M.; Delarocque-Astagneau, E.; Love, D.C.; Price, L.B.; Huynh, B.T.; Collard, J.M.; Guillemot, D. Bacterial Infections and antibiotic-Resistant Diseases among Young children in low-income countries (BIRDY) Study Group. Combating Global Antibiotic Resistance: Emerging One Health Concerns in Lower- and Middle-Income Countries. Clin. Infect. Dis. 2018, 66, 963-969. [CrossRef] [PubMed]

69. Asai, T.; Hiki, M.; Ozawa, M.; Koike, R.; Eguchi, K.; Kawanishi, M.; Kojima, A.; Endoh, Y.S.; Hamamoto, S.; Sakai, M.; et al. Control of the development and prevalence of antimicrobial resistance in bacteria of food animal origin in Japan: A new approach for risk management of antimicrobial veterinary medicinal products in Japan. Foodborne Pathog. Dis. 2014, 11, 171-176. [CrossRef] [PubMed]

70. Kyaw, M.H.; Lynfield, R.; Schaffner, W.; Craig, A.S.; Hadler, J.; Reingold, A.; Facklam, R.R.; Active Bacterial Core Surveillance of the Emerging Infections Program Network. Effect of introduction of the pneumococcal conjugate vaccine on drug-resistant Streptococcus pneumoniae. New. Engl. J. Med. 2006, 354, 1455-1463.

71. Cafiero-Fonseca, E.T.; Stawasz, A.; Johnson, S.T.; Sato, R.; Bloom, D.E. The full benefits of adult pneumococcal vaccination: A. systematic review. PLoS ONE 2017, 12, e0186903. [CrossRef] [PubMed]

72. Golding, G.R.; Quinn, B.; Bergstrom, K.; Stockdale, D.; Woods, S.; Nsungu, M.; Brooke, B.; Levett, P.N.; Horsman, G.; McDonald, R.; et al. Community-based educational intervention to limit the dissemination of community-associated methicillin-resistant Staphylococcus aureus in Northern Saskatchewan, Canada. BMC Public Health 2012, 12, 15. [CrossRef] [PubMed]

73. Awad, A.I.; Aboud, E.A. Knowledge, attitude and practice towards antibiotic use among the public in Kuwait. PLoS ONE 2015, 10, e0117910. [CrossRef] [PubMed]

74. Pavydè, E.; Veikutis, V.; Mačiulienè, A.; Mačiulis, V.; Petrikonis, K.; Stankevičius, E. Public Knowledge, Beliefs and Behavior on Antibiotic Use and Self-Medication in Lithuania. Int. J. Environ. Res. Public Health 2015, 12, 7002-7016. [CrossRef] [PubMed]

75. El Zowalaty, M.E.; Belkina, T.; Bahashwan, S.A.; El Zowalaty, A.E.; Tebbens, J.D.; Abdel-Salam, H.A.; Nohi, N.I. Knowledge, awareness, and attitudes toward antibiotic use and antimicrobial resistance among Saudi population. Int. J. Clin. Pharm. 2016, 38, 1261-1268. [CrossRef] [PubMed]

76. Klein, E.Y.; Van Boeckel, T.P.; Martinez, E.M.; Pant, S.; Gandra, S.; Levin, S.A.; Laxminarayan, R. Global increase and geographic convergence in antibiotic consumption between 2000 and 2015. Proc. Natl. Acad. Sci. USA 2018, 115, E3463-E3470. [CrossRef] [PubMed]

77. Hawking, M.K.; Lecky, D.M.; Touboul Lundgren, P.; Aldigs, E.; Abdulmajed, H.; Ioannidou, E.; Mappouras, D. Attitudes and behaviours of adolescents towards antibiotics and self-care for respiratory tract infections: A qualitative study. BMJ Open 2017, 7, e015308. [CrossRef] [PubMed]

78. Organisation Mondiale de la Santé. Campagnes Mondiales de Santé Publique de l'OMS. Available online: http:/ /www.who.int/mediacentre/events/2015/world-antibiotic-awareness-week/ antibioresistance-agir-affiche.pdf?ua=1 (accessed on 18 May 2018).

79. Asante, K.P.; Boamah, E.A.; Abdulai, M.A.; Buabeng, K.O.; Mahama, E.; Dzabeng, F.; Gyansa-Lutterodt, M.; Ghana Antimicrobial Resistance Working Group. Knowledge of antibiotic resistance and antibiotic prescription practices among prescribers in the Brong Ahafo Region of Ghana; a cross-sectional study. BMC Health Serv. Res. 2017, 17, 422. [CrossRef] [PubMed]

80. Organisation Mondiale de la Santé. Fédération internationale pharmaceutique. In Elargir la Pratique Pharmaceutique. Recentrer les Soins sur les Patients; OMS: Généve, Switzerland, 2006. Available online: http:/ / apps.who.int/medicinedocs/documents/s16219f/s16219f.pdf (accessed on 18 May 2018).

81. Bornstein, M.H.; Jager, J.; Putnick, D.L. Sampling in Developmental Science: Situations, Shortcomings, Solutions, and Standards. Dev. Rev. 2013, 33, 357-370. [CrossRef] [PubMed]

(C) 2018 by the authors. Licensee MDPI, Basel, Switzerland. This article is an open access article distributed under the terms and conditions of the Creative Commons Attribution (CC BY) license (http://creativecommons.org/licenses/by/4.0/). 